\title{
Janáček’s maestoso
}

John Tyrrell

Univerza v Cardiffu

Cardiff University

Unlike his contemporary Gustav Mahler, Janáček was unadventurous in his use of expression marks. He used very few, almost always preferring Italian to his native Czech. The most common words he used were espressivo, dolce and dolcissimo, which occur when he wanted to characterize particularly tender music. The only other expression mark he commonly used is the term maestoso [majestic]. As will be shown below, the occasions on which he employed the term can be easily classified - until his final opera $Z$ mrtvého domu [From the House of the Dead], where he appears to use it in rather different contexts and, if one bears in mind the meaning of the word, in a strange way. The object of this paper is to explore this phenomenon and suggest some interpretations.

The term maestoso has been current since the Baroque as an indication of mood or as a tempo designation. An early definition was given by J. G. Walther in his Musicalisches Lexicon oder Musicalisches Bibliothec (Leipzig, 1732), who described the term as "ansehnlich und langsam, iedoch mit einer lebhaften Expression" [stately and slow, but with a lively expression]. In his Musikalisches Lexikon (Frankfurt am Main, 1802) H. C. Koch stated that, like con gravità, maestoso could imply the use of overdotting. This can be found, for instance, in Haydn's slow introductions, especially the middle symphonies (e.g. no. 50 (1773): Adagio e maestoso; no. 53, "Imperiale" (1773): Largo maestoso; and no. 54 (1774): Adagio maestoso) though as David Wyn Jones has pointed out, while all Classical composers used maestoso, this 
was not always prompted by the expected dotted-note figuration any more than maestoso guaranteed dotted notes.

The changeover between the typical Baroque-Classical, often double-dotted maestoso and the nineteenth-century maestoso mood, came with Beethoven's Ninth Symphony (1822-4). The first movement begins Allegro, ma non troppo, un poco maestoso and sets the model for later nineteenth-century orchestral movements where maestoso is not confined to a slow introduction; instead a solemn, majestical mood permeates the whole movement.

While Mendelssohn's Symphony no. 2 (“Lobgesang”, 1840) adheres to the Classical-Baroque model of maestoso introductions to its first two movements, later orchestral works follow the model of Beethoven's Ninth with a maestoso indication that covers entire movements. Here are some examples:

Brahms: Piano Concerto no. 1 (1859), I: Maestoso

Max Bruch: Symphony no. 1 (1867), I: Allegro maestoso

Max Bruch: Symphony no. 2 (1870), I: Allegro passionato ma un poco maestoso

Brahms: Academic Festival Overture (1880): Allegro, later L'istesso tempo, un poco maestoso

Bruckner: Symphony no. 6 (1881), I: Majestoso [sic]

Towards the end of the nineteenth century maestoso began to be used for particularly grandiose effects. A well known example is the final movement of Tchaikovsky's Fifth Symphony (1888), marked Andante maestoso. This constitutes the slow introduction to the movement, giving way after almost sixty bars to an Allegro vivace. But near the end of the movement (bar 472) the opening theme returns now with relentless triplet accompaniment, the grandness emphasized by the "molto" in the direction Moderato assai e molto maestoso. Here the weight and grandeur of the maestoso has an almost theatrical dimension, a trait shared with another famous example, the climax of Saint-Saëns's Third Symphony (1886). To a large symphony orchestra Saint-Saëns added two pianos and an organ. And it is the organ with a full, held forte chord that initiates the twenty-four-bar section marked maestoso ( 16 bars after fig. R). The dramatic impact of this is enhanced by its context: it follows a soft, subdued section in constant diminuendo and then an orchestral pause. 
Outside the European mainstream, maestoso was often harnessed to a nationalist, patriotic, even triumphalist agenda. This can be seen for instance in the final movement (marked Moderato e maestoso) of Elgar's Second Symphony (1911), dedicated to the memory of King Edward VII, and in his Coronation March (for the new king George V, also 1911) with a Molto maestoso opening. However it was in Czech nationalist music that the patriotic maestoso came into its own. The more patriotically inflated sections of Smetana's six-part cycle Má vlast [My Fatherland] are studded with maestoso indications, as are parts of his heroic-patriotic operas Dalibor and Libuše.

In his third opera, Dalibor (1865-7) Smetana accompanied the entry of the Czech hero Dalibor with maestoso music, a march for full orchestra. But even before then the opera began with a scene-setting Largo maestoso (there is no prelude) to invoke the solemn scene as people await the trial of Dalibor who, in avenging the death of his friend Zdeněk, has killed his attacker. In this and other works Smetana associated the term maestoso with notions of Czech kingship, so that King Vladislav, although in some ways the villain of the piece, is generally accompanied with maestoso music: his arrival in Act 1 is announced by Subito maestoso trumpets. His first utterance in the opera, sung over held chords, is marked maestoso, the opening of Act 3, with the entrance of King Vladislav and his court, is marked Moderato maestoso and his exit at the end of the scene is again maestoso.

What can be seen here are essentially two sorts of uses of patriotic maestoso: an association with the Bohemian medieval kingdom and another with the heroic character of Dalibor himself. Such notions recur in Smetana's next opera Libuše (1869-72), an opera about the beginnings of the Czech kingdom, when the reigning princess Libuše chooses Přemysl as her consort and together they found the first Czech dynasty. Apart from a few bars of lento, the opening prelude is entirely maestoso. At the end of Act 1, there is a long ensemble culminating in Libuše, "con somma esaltazione", proclaiming her love for the Czech nation. These five bars are marked maestoso; and a short orchestral act-end that follows is Maestoso assai. Another important association comes towards the end of the opera when Libuše (a prophetess as well as a queen) foresees the future of the Czechs. In Libuše's prophecy, essentially a musical tableau vivant, one section is devoted to the Hussite wars. The Hussites were a proto-Protestant sect that arose from the teachings of the church reformer Jan Hus, mar- 
tyred by the Catholics in 1415 . When a Crusade was mounted against his followers they successfully defended Prague and for the next couple of centuries were able to maintain their distinctive Protestant-type religion. In order to invoke the Hussites, Smetana quoted their most famous chorale, "Ktož jsú boží bojovnici" [Those who are warriors of God] and marked it Andante maestoso.

In Smetana's symphonic cycle Má vlast the fifth movement, Tábor (the name of the Hussite town) is devoted to the Hussites. Much of the time in Tábor Smetana elaborates fragments of the chorale used in Libuše but towards the end there is an exciting straight-through version of the chorale, the culmination of the piece. At the climax of the movement, the Piu mosso is suddenly slowed down to a Lento maestoso before accelerating to the close. This device goes back to the last movement of Beethoven's Ninth Symphony where in the middle of the final Prestissimo the tempo is held back by a four-bar maestoso at the words "Tochter aus Elysium" - a sort of grand ritenuto before the Prestissimo returns to bring the work to a swift conclusion. Here the maestoso has a structural function. I shall call it an "Eleventh-hour maestoso".

As well as celebrating the heroic Hussites in the Tábor movement, Má vlast repeats Smetana's association with the Bohemian kingdom in the first symphonic poem Vyšehrad, named after the Prague castle associated with Czech kings. After the balladic harps that open the piece, the main theme is given out Largo maestoso. The final symphonic poem in Má vlast is called Blanik, named after the mountain where Czech warriors wait in readiness to save the nation. At the end Smetana combined a grand version of the $V y$ šehrad theme with the Hussite chorale from Tábor in a passage marked Largamente maestoso, moving through a Grandioso, meno allegro to a Vivace that concludes the piece, i.e. another "Eleventh-hour maestoso".

By taking the majestic nature of the term maestoso and the type of music associated with it and placing it against heroic moments in Czech history and moments celebrating the ancient Bohemian kingdom, Smetana provided a musical reinforcement of such patriotic thoughts that would then become an important trope for Czech music. I shall call this "heroic-patriotic maestoso". 


\section{Heroic-patriotic maestoso in Janáček}

Janáček's first use of the term is shown in ex. 1

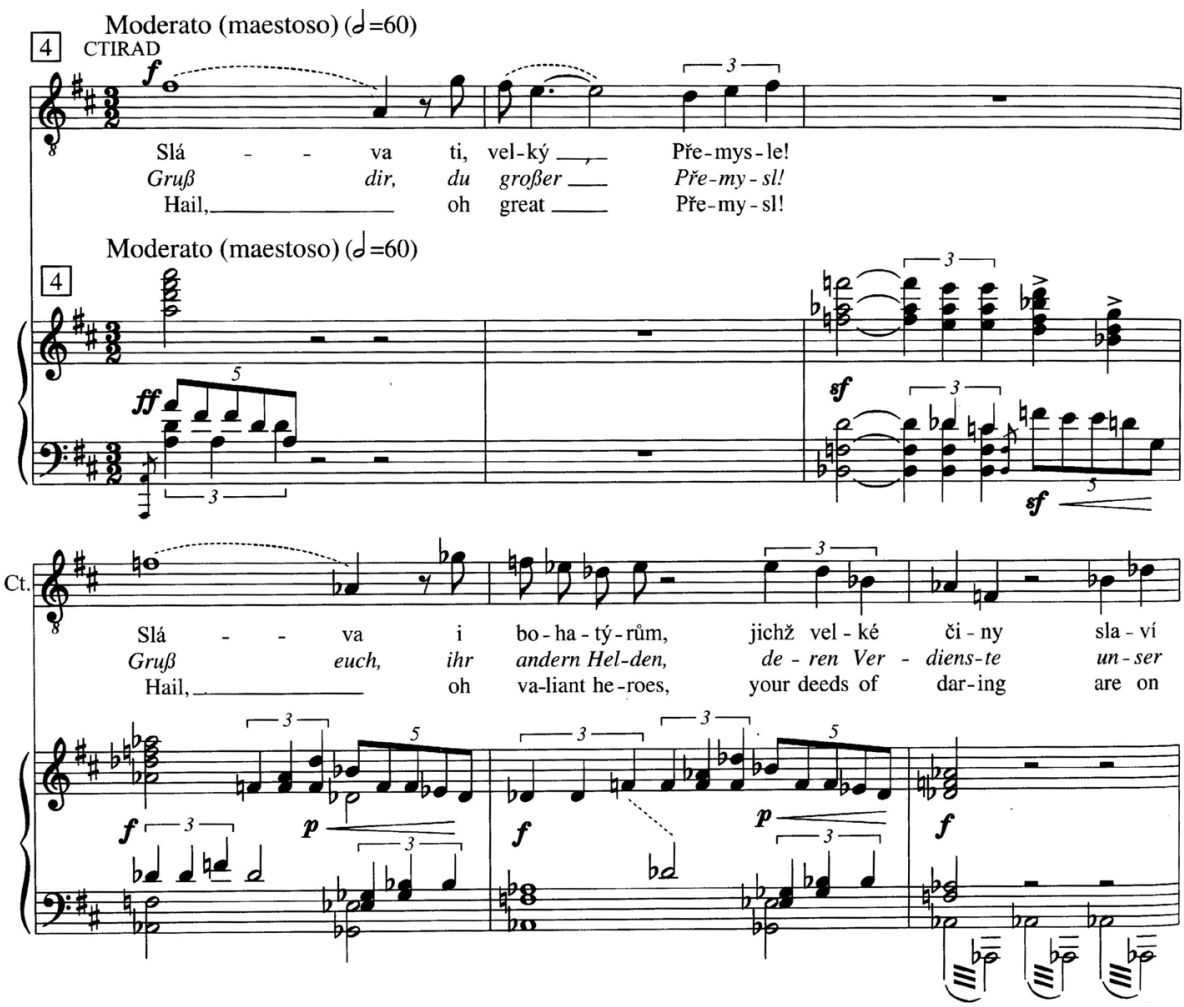

Example I: Janáček: Šárka, Act ı.C With kind permission by Universal Edition A.G., Wien, www.universaledition.com

This short passage comes soon after the beginning of Janáček's first opera, Šárka. Janáček wrote out a version of the opera in piano-vocal score in 1887 , but the next year, having shown it to Dvořák for his opinion and reacted to his criticisms, composed a second version. The opera is based on Czech mythic history and concerns events which took place after the death of the Queen Libuše. Her death meant there was not only a grieving widower (King Přemysl) but also an aggrieved female population, which had lost its female ruler. The women decide to take up arms against the men - the so-called "women's war" in which their most prominent fighter was Šárka. Soon after the opening of the opera, a young hero, Ctirad, arrives at the 
court of King Přemysl. The Moderato (maestoso) passage is Ctirad's greeting to the king and his warriors.

The version shown is one that Janáček revised thirty years later. The voice part (as in most of Janáček's 1919 revision of the opera) was much changed, but the orchestral accompaniment and its Moderato (maestoso) marking was there already in 1888 . Note the association of this marking with two characters: a hero (Ctirad) and a king (Přemysl). By doing so Janáček plugged into the Smetana tradition of associating maestoso music with heroes and Czech kingship.

Janáček had began as a Czech nationalist (his opera is a sequel to Smetana's Libuše), but this path was blocked: Šárka did not reach the stage until 1925 because the author of the text - whom Janáček had not consulted - refused his permission for it to be used. And so Janáček turned his back on this type of music altogether and instead began his involvement with Moravian folk music, which, after a few years, would transform his style and begin to move it nearer to the music now associated with him.

Janáček employed no more heroic-patriotic maestoso markings for almost thirty years since none of the music he composed during this time called for it. However, towards the end of the First World War the Habsburg Empire began to show signs of collapse and there was thus hope of realizing the nationalist dream of an independent Czech nation, Janáček, by then famous and successful, made his contribution with a group of patriotic pieces between 1917 and 1920 which employed heroic-patriotic maestoso. These comprise:

Výlety pana Broučka: Výlet pana Broučka do XV. století [The Excursions of Mr Brouček:The Excursion of Mr Brouček to the Fifteenth Century], opera (1917);

Taras Bulba, symphonic rhapsody (1918);

Ballada blanická [The Ballad of Blaník], symphonic poem (1919-20).

The Excursion of Mr Brouček to the Fifteenth Century takes the Prague nineteenth-century landlord Mr Brouček back to the heroic time of the Hussites and their defence of Prague in 1420. Musically this is characterized by Hussite chorales (Janáček used the original words but wrote new musical settings for them). One of the chorales, "Slyšte, rytieři boží" [Hear ye, warriors of God], is threaded through Act 1, each time marked maestoso, heard at first 'from afar' sung by the 'Armed People' (Ozbrojený lid), 
more loudly as they approach and finally fortissimo and maestoso as the act's conclusion.

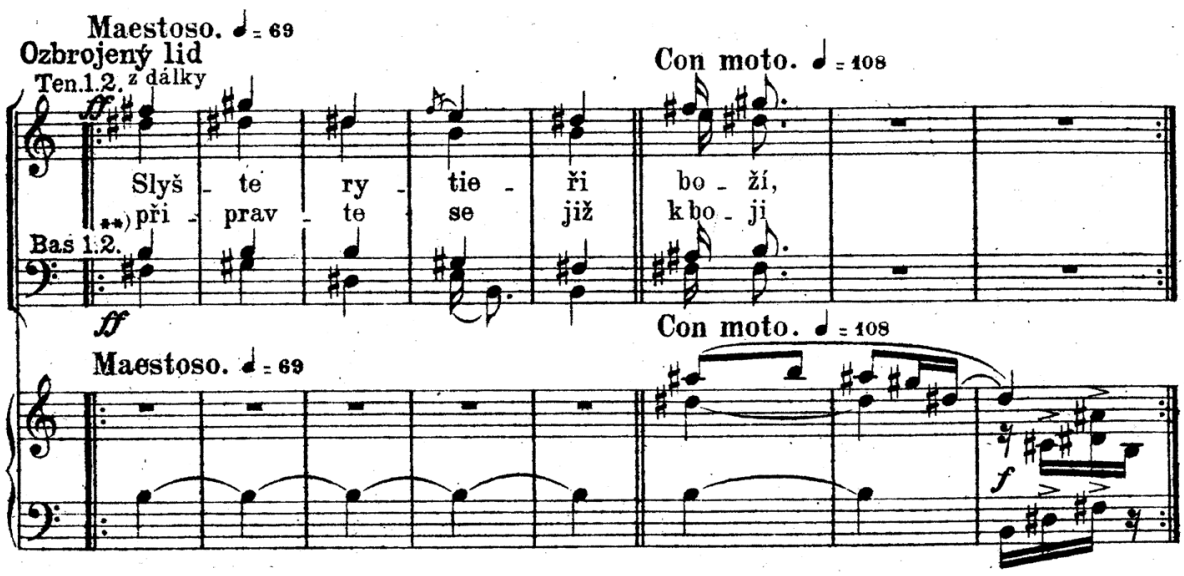

Example 2: Janáček: Výlety pánè Broučkovy: Výletpana Broučka do XV.století, Act I. (C) With kind permission by Universal Edition A.G., Wien. www.universaledition.com

This is not the only maestoso marking in the Fifteenth-Century Excursion. Soon after the beginning, a drunken Mr Brouček loses his way in the cellars of Vikárka pub and imagines that he has been transported back to the fifteenth century and into the jewel-chamber of King Václav [Wenceslas] IV. There is a maestoso marking (against grandiose music) when $\mathrm{Mr}$ Brouček manages to light a lamp and gets a glimmering of where he has ended up. Soon after, the author of the Brouček novels, Svatopluk Čech, is brought on stage to sing an invocation to the decisive day of battle ("Slunce velkého dne" [Sun of the great day]), once again marked maestoso.

A more ambiguous moment comes in Act 2 when Kunka, the daughter of Brouček's fifteenth-century host and protector Domšík, returns shattered from the battlefield. The mainly orchestral music is marked maestoso, which hardly seems to fit the initial despondent mood, but against this an ascending figure suggests a hopeful outcome to the battle, soon confirmed by a jaunty victory march and by another Hussite choral ("Dítky, $v$ hromadu se senděme") [Children, let's get together], again marked maestoso, sung by Kunka's lover Petřík and the chorus.

Janáček began composing his three-movement "rhapsody for orchestra" Taras Bulba, in 1915, in the early stages of the First World War in reaction to encouraging news from the front with early Russian victories 
against the Habsburgs (Janáček hoped at this point that the Russians would "liberate" their Slavonic brethren from the Habsburg yoke). Gogol's novella, the inspiration for Janáček's work, is a chapter in the history of how the Ukraine was gained for Russia from the Poles and Lithuanians. The chief character is the Ukrainian Cossack Taras Bulba, seen at the beginning taking his two young sons off to the fighting grounds to achieve their manhood. All three are killed.

As the Russians' war fortunes faded and the unlikelihood of getting a performance of a large-scale symphonic work seemed to have dawned on Janáček, he put the work aside until 1918. By then his own fortunes had changed with the huge success of his opera Jejípastorkyña [Jenůfa] in Prague as had the balance of forces in the war with the entry of the Americans.

The third movement of Janáček's work is entitled "Proroctví a smrt Tarase Bulby" [The prophecy and death of Taras Bulba]. The "prophecy" is Gogol's Russian chauvinist dream of the ultimate triumph of Russia and its Orthodox faith put into the mouth of Taras Bulba as he dies at the stake: "A tsar shall arise from Russian soil, and there shall not be a power in the world which shall not submit to him". In one of Janáček's commentaries on the work he wrote (adapting Gogol's own conclusion) that "such fires or tortures that could destroy the strength of the Russian people cannot be found on earth". By 1918, with the installation of a Bolshevik Government (which Janáček disapproved of), Janáček's Russophilia had somewhat abated. He deleted the word "Slavonic" from its original title ("Slav. rhapsodie" [Slavonic Rhapsody]) and transferred the triumphalism of the final movement to a more Czech-patriotic use with his later, though unofficial, dedication of the work to the Czechoslovak Armed Forces.

Janáček's music in the third movement includes an eight-bar maestoso section (bars 44-51) with a $p p$ melody marked dolcissimo on the violins answered by cor anglais and harp. As the work nears its end the overwhelmingly grandiose atmosphere is enhanced by two more brief maestoso passages (bars 123-8; bars 191-6). By the last of these the large orchestra has been swelled by addition of an organ.

Janáček's Ballad of Blaník, dedicated to the Czechoslovak President "the liberator T. G Masaryk", is a messianic work commemorating the same mountain that featured in Smetana's Má vlast. Maestoso markings appear early in the work. At bars 54-5 there is a two-bar motif played on horns and two harps (the harps reminiscent not only of those in Taras Bulba but also in Smetana's balladic maestoso harps in Vyšehrad). It is interrupted by a 
three-bar passage marked Vivo, and then resumes in the same texture with another short maestoso section. Although brief, the motif is important in the piece, to be brought back towards the end (bars 273-81), in a Meno section (though Janáček's autograph is marked maestoso at this point) which puts together the two previous maestoso sections without the Vivo interruption. Again the motif is played on two harps (though not horns, and with a fuller orchestral background). What is remarkable is that the motif is in fact the same as that found in Taras Bulba at bars 195-8, i.e. bars directly continuing from the third of the maestoso sections mentioned above. Although the purpose of the two symphonic works could not be more different, one a glorification of war, the other a plea of peace, both share similar maestoso apotheoses.

\section{Structural maestosos in Janáček, I: endings}

Though not particularly sympathetic towards Smetana, Janáček knew all the Smetana pieces described above and from the examples given it would appear that he took on board Smetana's distinctive uses of the term maestoso. He was, however, much more in tune with Smetana's younger contemporary, Antonín Dvořák. Dvořák's Seventh Symphony in D minor (1885), which Janáček conducted in Brno in 1886, has a first movement marked Allegro maestoso, the final movement concludes with a Molto maestoso. There is also a ten-bar "Eleventh-hour maestoso" in the final movement of Dvorák's Cello Concerto marked Andante maestoso before accelerating into a concluding Allegro vivo. Some of the pieces by Dvořák that Janáček knew particularly well were the four late symphonic poems based on poems by Karel Jaromír Erben: Vodník [The Water Goblin], Polednice [The Noonday Witch], Zlatý kolovrat [The Golden Spinning Wheel] and Holoubek [The Wild Dove]. Janáček published long analyses of them (JW XV/152, $\mathrm{XV} / 153, \mathrm{XV} / 154, \mathrm{XV} / 156)$ and even gave the first performance of the last one, The Wild Dove. Based on Bohemian folk-legend, the Erben symphonic poems have a patriotic cast to them and Dvoŕák used maestoso markings in all but one. There is, for instance, a Grandioso e maestoso section associated with the King in the Golden Spinning Wheel.

The really interesting one in this connection is The Noonday Witch, which has no association with kings or heroes. Apart from a one-bar stringendo, the final twenty bars are marked maestoso and constitute the dramatic end to the piece: a mother looking after a fractious child threatens it with the Noonday Witch. The father returns to find the mother in a faint 
with the dead child pressed to her bosom, its life taken by the Witch. The music here describes the horror of the parents as they realize what has happened - a depiction of supernatural horror.
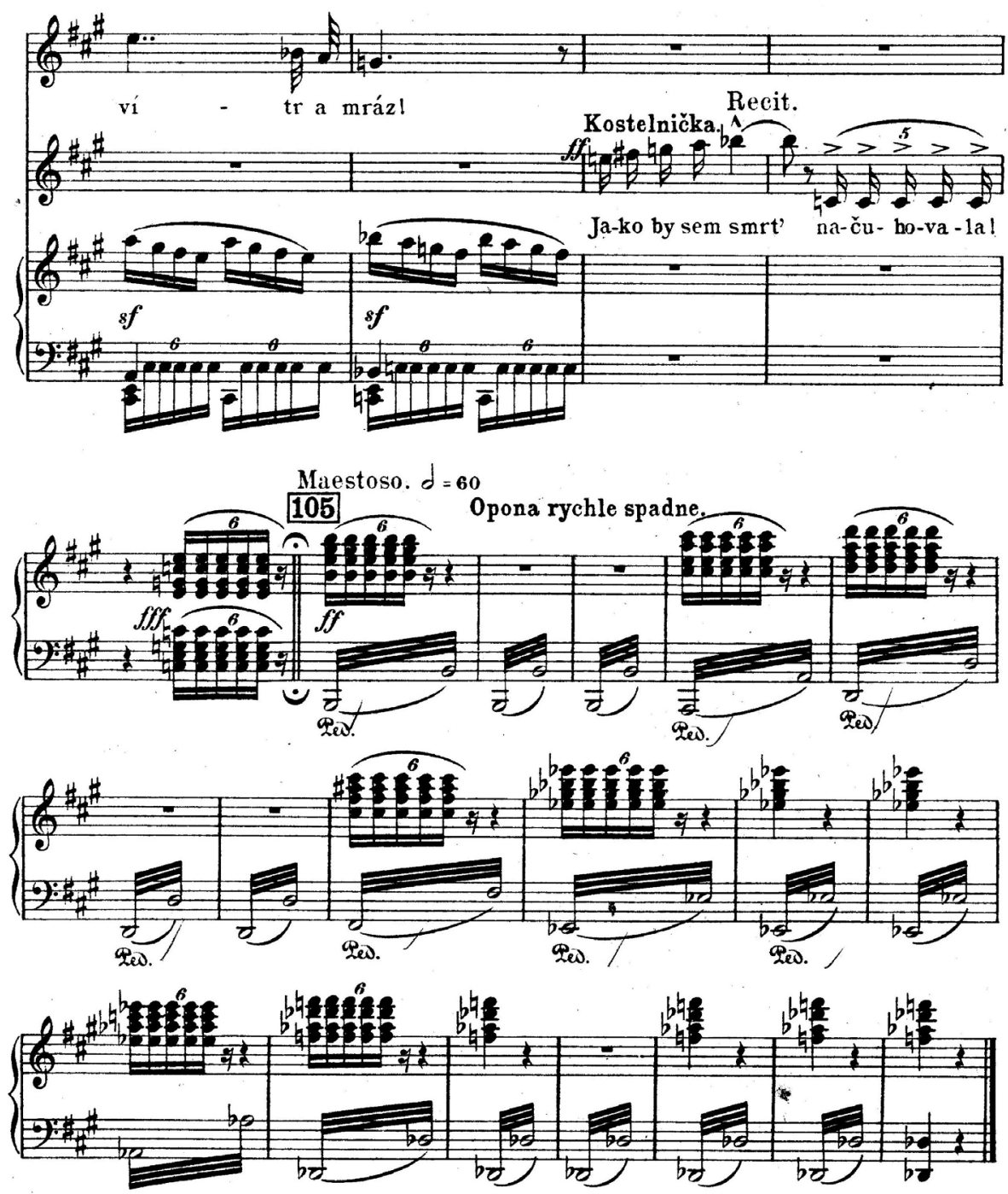

Example 3: Janáček: Jejípastorkyña (piano-vocal score published by Přátel uměnív Brně, 1908), Act 2. 
A few years after Dvořák composed his symphonic poem, Janáček embarked on the long journey of writing his third opera Jenúfa, finally completed in 1903 and staged in Brno in January 1904. Like the end of Dvořák's Noonday Witch, Act 2 concludes with a maestoso passage, invoking an almost supernatural frisson as the Kostelnička, who has returned from murdering her beloved stepdaughter's baby in the frozen river, begins to realize of the enormity of the crime she has committed and imagines death knocking at her door ("Jakoby sem smrt' načuhovala"). She utters these words in a dramatic, unaccompanied cry, the five syllables of her final word "na-čuho-va-la" echoed by the five chords in the orchestra which then launches the terror-filled orchestral maestoso based on this rhythm as the curtain falls (see ex. 3).

This type of concluding maestoso became a favourite in Janáček's operas for act endings, heightening the drama of what has just occurred on stage and bringing the act to a forceful conclusion. Examples can be found in:

Její pastorkyña [Jenůfa], opera (1903): end of Act 2; end of Act 3;

Osud [Fate], opera (1907): end of Act 2; end of Act 3

Šumařovo ditě [The Fiddler's Child], symphonic poem (1913): end;

Výlety pana Broučka: Výlet pana Broučka do XV. století [The Excursions of Mr Brouček: Excursion to the Fifteenth Century], opera (1917): end of Act 1;

Káta Kabanová, opera (1921): end of Act 1; end of Act 2; end of Act 3 ;

Př́hody lišky Bystroušky [The Cunning Little Vixen], opera (1923): end of Act 3;

Věc Makropulos [The Makropulos Affair], opera (1925): end of Act 2 ;

Sinfonietta (1926), end of movements I and V.

All of Janáček's operas from Jenůfa onwards include at least one maestoso act-ending (the Brouček example of course counts also as a heroic-patriotic maestoso). But Janáček did not confine the use to operas. Large-scale orchestral works such as his symphonic poem The Fiddler's Child conclude with a maestoso marking. His Sinfonietta has two because the Fanfare opening, where it first occurs, is recapitulated at the end of the work, now with the whole orchestra joining in the brass fanfares of the opening movement. 
These concluding maestosos can be further divided. The Act 2 Jenüfa can be categorized as melodramatic and exciting, but the orchestral conclusion to Act 3 of the opera (fig. 82), after the touching scene of forgiveness between Jenůfa and Laca, marked Maestoso con moto, is instead a type of redemptive, transcendental maestoso that can be found, for instance at the end of The Cunning Little Vixen. The six-bar maestoso orchestral conclusion to Fate Act 2 (Scene 5, bars 133-8) after Živný's discovery of the dead bodies of his wife Míla and her mother is clearly melodramatic. Makropulos Act 2 has a more substantial maestoso ending. It begins straight after Emilia Marty has demanded from Jaroslav Prus the envelope containing the formula for her father's elixir of life. A fortissimo orchestral unison, with a sforzando cymbal roll rings out, maestoso (bars 975-95). In its final bar Prus asks "A kdy?" [And when?], i.e. when would be their assignation in payment for the envelope. A softer, more relaxed Andante accompanies the pair's brief exchange, but Prus's final "Platí" [Agreed!] initiates the maestoso (bars 9921003), which brings the act to an end - another melodramatic act-ending.

All three acts of Káta Kabanová end in maestoso. The nine-bar orchestral conclusion to Act 1 (fig. 33), with Tichon's departure despite Káta's pleas for him stay (she rightly fears that her feelings for Boris will lead to disaster) is another, melodramatic maestoso, as is the seven-bar orchestral maestoso conclusion to Act 3. Here after Káta's suicide and her mother-in-law's triumph over the corpse Janáček combines the prominent themes of the voices of the Volga (calling Káta to her death) with the eight-note timpani theme (portending fateful events) heard in the early bars of the overture. By contrast, the conclusion to Act 2, as Káta slowly departs after her meeting with Boris, belongs to the transcendental type. Radiant fortissimo E-major chords (an unusual key for Janáček) highlight what has surely been the happiest moment of Káta's adult life. After the initial outburst, the chords slowly move down from their initial height and a double bass and then cello solo lead into the end of the act where the maestoso gives way to five bars of cadential Adagio.

It is not easy to characterize the maestoso at the end of The Fiddler's Child. If the composer is adhering at all to the story of Svatopluk Čech's poem that gives Janáček's symphonic poem its name, this is the point after the Mayor (the villain of the piece) has discovered the corpse of the fiddler's child: a melodramatic situation. But the long maestoso that follows (bars 438-84), after its initial fortissimo chords, soon subsides, producing a subdued ending that suggests pathos rather than transcendence. The same 
however cannot be said for the exuberant, apotheotic, maestoso ending of the Sinfonietta, a thrilling medley of trilling woodwind and strings over the brass fanfares of the first movement. Like the Káta Act 2 example, it does not end maestoso: seven bars of Adagio are devoted to a prolonged cadence.

Apart from the few words in Makropulos Act 2 and the Hussite chorale of Brouček's Excursion to the Fifteenth Century, Act 1 all of Janáček's maestoso act-endings in his operas are purely orchestral.

\section{Structural maestosos in Janáček, II:}

\section{Eleventh-hour maestosos}

Like Smetana and Dvořák before him Janáček also made use of "eleventh-hour maestoso". These present a rather more varied use and occur not only in operas, but in choral-orchestral and even chamber works:

String Quartet no. 1 (1923), IV: maestoso before the final Più mosso; The Makropulos Affair (1925): maestoso interlude before Marty's farewell in Act 3 (effectively the end of the opera);

Mša glagolskaja [Glagolitic Mass] (1926): maestoso episodes before the end of movements III and IV

Capriccio for piano left hand and wind ensemble (1926), IV: piano cadenza marked maestoso towards end of the movement

Although the grand associations of maestoso means that the term is seldom found in chamber works, Janáček made a few exceptions. The sixbar maestoso in the last movement of his First String Quartet (at bar 121) resembles the classic "eleventh-hour maestoso" in that it gives way to a Più mosso that brings the work to a close, heightened towards the end with a Più mosso (feroce). However the Maestoso Tempo I is less an interruption of the preceding Adagio than itself an intensification of it.

Janáček's Capriccio for piano left hand, flute/piccolo, two trumpets, two tenor tubas and three trombones has what is virtually a piano cadenza before the end of the work. At bar 134, thirty bars before the cadenza, there is a section, at first confined to the brass, marked maestoso-vivo (a most unusual combination). The brass bars highlight a theme, previously merely subsidiary, on which the rest of this section is based. Tempos are fast or moderate until a sudden Adagio at bar 163, two bars before the cadenza. Together the Adagio and the grander, two-bar beginning of the cadenza (marked maestoso) constitute a brief holding back of the tempo before 
plunging into Prestissimo for solo piano. After twenty bars the flute joins in, followed by the rest of the ensemble as the piece moves towards its close. Apart from the Grave for the final twelve bars this gives the impression of a rather more elaborate "eleventh-hour maestoso".

Towards the end of The Makropulos Affair, Emilia Marty tells her mysterious story as, among her hearers, disbelief turns slowly to grudging acceptance. She collapses, a doctor is called, and she is taken into the bedroom of her hotel suite. Fast and furious orchestral music, high and full of trills, gives way after eighteen bars to a passage marked maestoso (at bar 810). At first there are slow and solemn brass chords; then a theme, at first on a solo violin, transfers to the viola d'amore (an instrument which Janáček used occasionally to convey especial tenderness) and then, after the viola d'amore has ascended to the top of its range, a full forte orchestral version takes over, again marked maestoso (though no other instruction has intervened). An Adagio follows with the reappearance of Marty, described in the stage direction as "jako stín" [as a shadow], "a pale green light overflowing the stage and auditorium" contributing to the other-worldly atmosphere. This is the beginning of the finale in which Marty comes to terms with her mortality and accepts death.

With great clarity this passage depicts a change of state. Something is going on that transforms Emilia Marty from the bossy, confident figure we have seen so far, determined to get the formula to give her another three hundred years of life, into someone quietly reconciled to death. The long orchestral maestoso before the final scene is a structural marker, a development of the "eleventh-hour maestoso", but this wonderful section is also an example of what one might call a "redemptive maestoso".

There are more uses of maestoso as a near-end structural marker in two movements of Janáček's Glagolitic Mass In the third movement, “Slava" [Sanctus], a long passage starting "Sědej o desnuju otca" [Sitting at the right hand of the father] (bar 139) marked maestoso is dominated by the tenor solo (with increasing support from the chorus) though when the chorus takes over completely the pace increases to a Un poco mosso moving through Allegro with the return of the solo tenor, then Presto and finally a purely orchestral Allegro of nine bars to close the piece.

In the next movement, the "Veruju" [Creed] a long orchestral section describes Christ's suffering on the cross. The chorus comments briefly "raspect že zany, mučen i pogreben byst" [He was crucified also for us, he suffered and was buried] after which a five-bar maestoso (bar 244-8) on full orchestra including the organ, fortissimo, gives way a new Andante 
section, set vocally for chorus. This is more a marker for the central point in the narrative than an "eleventh-hour maestoso". However another maestoso occurs a little later that fulfils this function. The chorus repeats the hushed "Věruju" opening, which is followed by a five-bar orchestral maestoso, fortissimo (bars 336-40), the chorus overlaps in the first bar) heralding what is in effect the finale of the movement. After a pause bar the orchestra continues with a new swirling accompaniment against the tenor's words "Katoličesku i Apostolsku Crkov" [(I believe) in the Catholic and Apostolic Church]. A Un poco più mosso follows and drives to the movement to its end. The scale of this example and the Makropulos finale is of course very different from that in the final movement of Beethoven's Ninth Symphony, which is no more than an extended ritenuto. But the function is the same: a distinctive holding back before a section brings the movement or the act to a climactic end.

\section{Highlighting important words}

Most of the examples encountered so far in Janáček's operas have been purely orchestral. However, in a few cases in Janáček's operas words crucial to the plot are highlighted either by having them sung against a maestoso passage, or by placing a maestoso passage immediately afterwards. Thus in the final pages of Act 1 of Janáček's first opera, Šárka there is a three-bar section (fig. 30) marked Poco lento (Maestoso). Two orchestral bars announce a variant of the theme which will, at fig. 31, constitute the Adagio finale of the act, the first of Janáček's “slow cathartic waltzes". In the third bar of this marked Poco lento (Maestoso) the orchestra pauses for the temporarily defeated Šárka to declare "příšerně" [viciously] "Krví tvou záští ukojím” [I"ll assuage my anger with your blood!], a sentiment that will spur on her actions in the next act, culminating in the death of her male rival, Ctirad,

At the end of the first act of Fate Míla elopes with her lover Živný. The reaction to this by Míla's mother is decisive. In Act 2, Živný and Míla and their little son are living together. But with them is Míla's mother, whose horror at their out-of-wedlock liaison has driven her mad: her actions at the end of the act lead to her and her daughter's death. When in Act 1 Míla's mother hears of the elopement she cries out "To ne! To snad ne! S panem Živným!” [No! Surely not! With Mr Živný!] to which the orchestra reacts with a six-bar maestoso, fortissimo (Scene 15, bars 22-7).

In Káta Kabanová, Act 3 Scene 1 Dikoj, having heard what he regarded as a flippant answer to his question of what a storm is ("just electricity”), 
gives his own portentous explanation: "Bouře je za trest na nás abychom moc boží potitovali" [Storms are our punishment so that we feel the might of the Lord] (7 bars after fig. 5). His words are given out "přesvědčivě" [persuasively] in a maestoso passage of four bars against the theme (heard later in the act) of the voices that call Káta to her death. The storm depicted in this scene unnerves Káta to make her public declaration of adultery and, in the next scene, to seek her death.

In the final scene of the opera, Káta wanders alone, contemplating her fate and wanting death. She longs to see Boris and then, in what up to now has been a mainly soft soliloquy, she calls out, forte, "Vy větry bujné! Doneste mu žálostný můj stesk!" [Abundant winds, carry my sad longing to him!]. The four-bar passage (4 bars before fig. 27), is marked maestoso, and Káta's memorable tune is emphasized by the orchestra playing it in unison with her. Not long after, her wish is granted: Boris appears for a brief farewell scene before she throws herself into the Volga.

Finally, in The Makropulos Affair, in the middle of Marty's long story about her strange life she comes to describe how the Emperor Ferdinand, who has demanded her father make up an elixir of life for him, now insists that it be tried first on the young Elina Makropulos. Emilia's last word "zkusil" [tried] overlaps into an orchestral maestoso of five bars (bars 71115), at first a purely orchestral reaction, and then while the orchestra pauses on a single chord (as in the Šárka example above), she sings: "Pak jsem byla týden či jak dlouho bez sebe a uzdravila" [Then I was unconscious for a week or so, and got better], after which she resumes her narrative, the tempo now marked Moderato. The maestoso here underlines the fact that it was the young Elina Makropulos (now Emilia Marty) who, rather than the Emperor, was given the magic formula which has prolonged her life by three hundred years, the underlying basis for the plot of the opera.

\section{Marking important moments}

All the maestoso underlining of important words described above are short passages. But Janáček also used longer sections of maestoso to draw attention to important moment in a work. In Fate there is a long, purely orchestral passage (Scene 2, bars 143-200) marked maestoso. It comes early in Act 1 and therefore has none of the functions of the structural maestosos described above. However the length is striking and this long orchestral passage helps to highlight an important moment in the opera when Míla has caught sight of her former lover Živný, from whom she has involuntarily 
parted (the rest of Act 1 will see their reconciliation and finally elopement). The drama of the situation is furthermore heightened by the last eight bars (the maestoso marking is repeated) in which the texture thins down to tremolo violins, playing a triple forte version of the theme on which the maestoso passage before was based. Voices are heard only in the final two bars, after which normal conversation between the group (Míla and Živný and two others) resumes, the tempo now changed to moderato.

Janáček used the maestoso indication three times at the end of Act 3 of Fate. In response to the students' invitation to describe the opera to be given that evening Živný begins a long narration which, as he explains the plot, also reveals his personal involvement - it is in fact his story, and by the first maestoso (at Scene 3, bar 47) his utterances have become incoherently passionate and visionary, the transcendental mood emphasized by the widespaced orchestral accompaniment to his words. The students to whom this is addressed register their horror but Živný continues (Scene 4 with the maestoso seemingly continuing) describing the vision of his dead wife until he collapses in a faint, a total of thirty-four bars. A second maestoso comes a little later (Scene 4, bar 53) as the anxious students try and calm Živný, who attempts to echo the notes that he hears his dead wife singing. But when the student Verva suggests that this is from the missing last act of the opera Živný sits up and declares robustly "To jest v rukou božích a zůstane tam!" [That is in the hands of God and will stay there!]. These words are sung unaccompanied and maestoso. Then follows eleven bars of purely orchestral music that concludes the opera in high drama.

While the final maestoso in Fate can be regarded as a Structural I maestoso the other uses in this act help to underline the visionary, transcendental state that takes over Živný in his increasingly personal description of the opera.

This use of maestoso to create a strange, otherworldly atmosphere can be found outside Janáček's operas. In the second movement (bar 131) of his Sinfonietta the previously brisk tempo is halted by a strange maestoso with held wind chords, high violin and viola figuration pierced by Janáček's trumpets and then trombones in one of Janáček's more unusual time signatures (13/8). The uneven metre, and wide-spread orchestration combined with the maestoso marking contributes to a feeling of time standing still. It gives way to a Più mosso until arrested again by another maestoso with similar effects (though varied means). This strange maestoso section con- 
stitutes a central moment of timelessness in contrast to the otherwise busy outer sections of the movement.

Janáček used the same device in the fifth movement of the same work (bar 100) when the impetuous Più mosso, which has been driving the movement towards a climax, is suddenly interrupted by a six-bar maestoso. Again he used a wide-spread texture: growly thick trombones at the bottom, high tremolo violins at the top against which a very high flute wanders down, alternating and then combining with an E flat clarinet until swept away by a return to the previous Più mosso as the music heads towards an exciting climax with the return of the fanfares and its maestoso climax.

[71-72] Ty vlnky mé zlaté Kamily.

$5 / 1 / 1 / 1028$

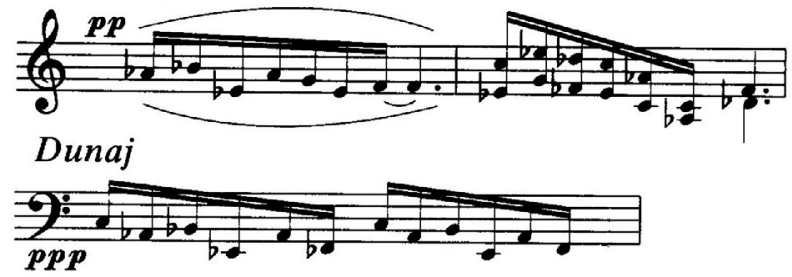

vlnka lká:
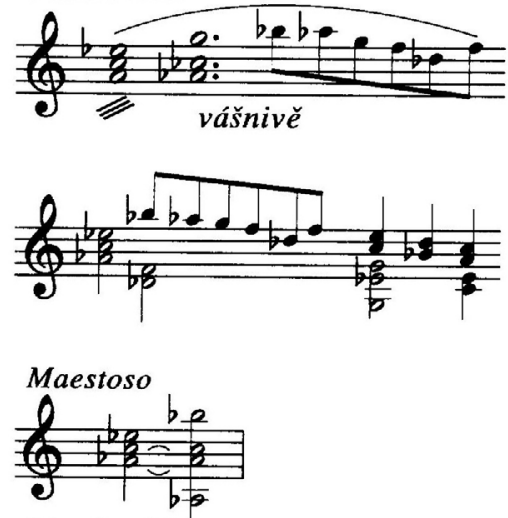

Ta slast!

Example 4: Janáček: Památnik pro Kamilu Stösslovou, ed. and transcribed by Jarmila Procházková (Brno: Moravské zemské muzeum,1994).

One of Janáček's more puzzling maestoso markings comes in the second movement of his Second String Quartet "Listy důvěrné" [Intimate Letters] at bar 6o. Here a theme already heard fortissimo four bars earlier is 
played again and elaborated for eight bars marked maestoso in espressione, a slowed-down intensification of the music before a Vivace continuation. Some clue as to what this meant for Janáček can perhaps be provided by a tiny fragment jotted down in the Památník pro Kamilu Stösslovou [Album for Kamila Stösslová], dated 5 August 1928, a week before he died and a few months after completing the Second String Quartet. Here, having written out themes to represent "Ty vlnky mé zlaté Kamily" [The waves (i.e. breasts) of my dear Kamila], and others to show the waves crying "passionately" ("vlnká lká"; "vášnivě") he writes two chords (the second very spread out), marked maestoso with the comment "Ta slast!" [That bliss!] (see ex. 4).

Janáček's maestoso passages in the years up to his last opera, From the House of the Dead, have a number of shared characteristics. They are mostly loud and slow, generally providing a contrast in speed to what comes before and (unless they end a piece) after. While some more extensive examples can be found, most are short sections. Apart from a few instances where Janáček used maestoso to highlight important words of moments in operas, Janáček limited his uses of maestoso to purely orchestral (or instrumental) music. Generally the marking is always appropriate to the solemn or majestic or occasionally otherworldly mood. Their uses can be categorized as follows:

a. Heroic/patriotic nationalism;

b. Structural (I): conclusion of act or movement;

c. Structural (II): dramatic stopping-point towards the end of a piece, followed by a precipitate close (= "11th-hour Maestoso")'

d. For highlighting important words;

e. For marking important moments;

f. To suggest a transcendental, visionary quality.

\section{Maestoso in From the House of the Dead}

The oddity of the way in which Janáček used maestoso in From the House of the Dead becomes clear when his usage there is compared to that in the three proceeding operas.

Káta Kabanová (1921): 5 occurrences: 
3 structural (ends of Act 1, Act 2 and Act 3);

2 key words, all Act 3: Dikoj declares that storms are a punishment from God to show his might; Káta calls out to Boris before their final meeting.

The Cunning Little Vixen comment. (1924): 1 occurrence:

1 structural (end of Act 3).

The Makropulos Affair (1926) 4 occurrences:

2 structural (end of Act 2, end of Act 3);

1 suggesting a transcendental change of state for Emilia to emerge "like a shadow", Act 3;

1 for important words, Act 3: Marty describes how they tried out the formula years on her and thus gave her a three-hundred-year life span.

In From the House of the Dead Janáček used maestoso in the following places:

A: Overture, bars 141-2

B: Act 1, bars 154-64: Arrival of Petrovič at the prison camp (orchestra only): includes motto theme;

C: Act 1, bars 327-8: Prisoners tell Nikita to release the eagle;

D: Act 1, bars 607-12: Prisoners dismiss the crazy Skuratov as a "useless fellow"; includes motto theme;

E: Act 3, bars 35-8: Prelude: end; this music recurs at end of the opera to words about freedom and the release of the eagle;

F, G, H: Act 3, bars 602-9, 759-72, 826-37): three important moments in Šškov's story about Akulka; $\mathrm{H}$ includes the motto theme.

The two-bar maestoso in the overture has all the hallmarks of an "eleventh-hour maestoso". It occurs towards the end after a long Allegro passage and is immediately swept aside by a Presto and then Allegro, which drives the music towards its climactic end.

As the summary above show, five of the uses of maestoso include sung words (C, D, F, G, H). To deal with these first, example $C$ has just three words, but these are key words to the opera. Janáček made a clear link between the eagle with a broken wing kept by the prisoners and Alexandr Petrovič Gorjančikov, whose arrival soon after the beginning of the opera 
and his departure at the end of opera constitutes the chief narrative thread of the piece. When Petrovic has been taken off to be beaten (we hear his cries of pain offstage), the prisoners bring out the eagle. They tell his keeper, Nikita, to release him - just two bars marked "Maestoso". But the eagle's wing is still broken and he is unable to fly. "Orel, car lesư" [Eagle, tsar of the forests!] the prisoners sing ironically. These are important words that are heard later in the opera.

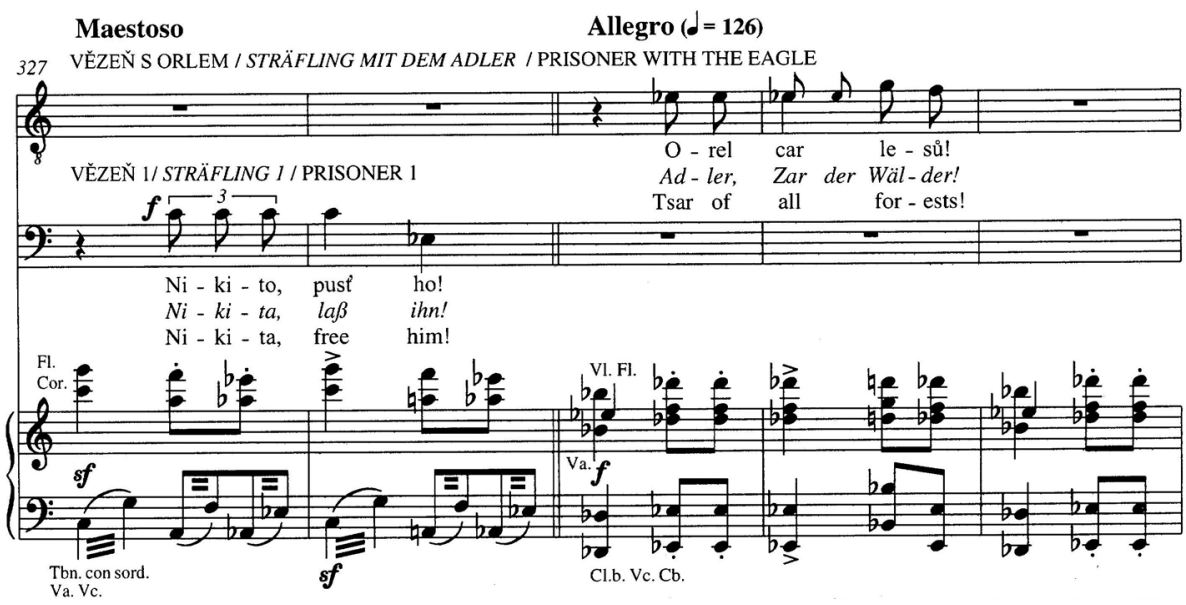

Example 5: Janáček: From the House of the Dead, Act I. (C) With kind permission by Universal Edition A.G., Wien. www.universaledition.com

The third act is dominated by the longest narrative in the opera, Šiškov's harrowing tale of how he married and murdered Akulka. He was persuaded to marry Akulka after his friend Filka Morozov has told all the village that he has slept with her and thus disgraced her. She is now considered damaged goods and the good-for-nothing Šiškov is encouraged to take her on. But, after the marriage when the couple have been left alone, he discovers that she is in fact a virgin - "Čistá, nevinná! Čestná z čestného rodu" [Pure, innocent! An honourable woman from an honourable family] he declares in a passage marked maestoso (from bar 602), Akulka's purity matched by the purity of the harmony and the dolcissimo marking.

Later in the same narrative Šiškov describes how Filka Morozov goes off to the army in place of a conscripted recruit. As Filka passes by Akulka's house he sees her. He jumps down from the cart and, bowing low before her, tells her that he has loved her for three years. The moment when 
he asks her forgiveness for maligning her is when the second of the three maestoso passages occurs. Although Šiškov is a baritone, normally notated in the bass clef Janáček notates Filka's reported words as if sung by a tenor.
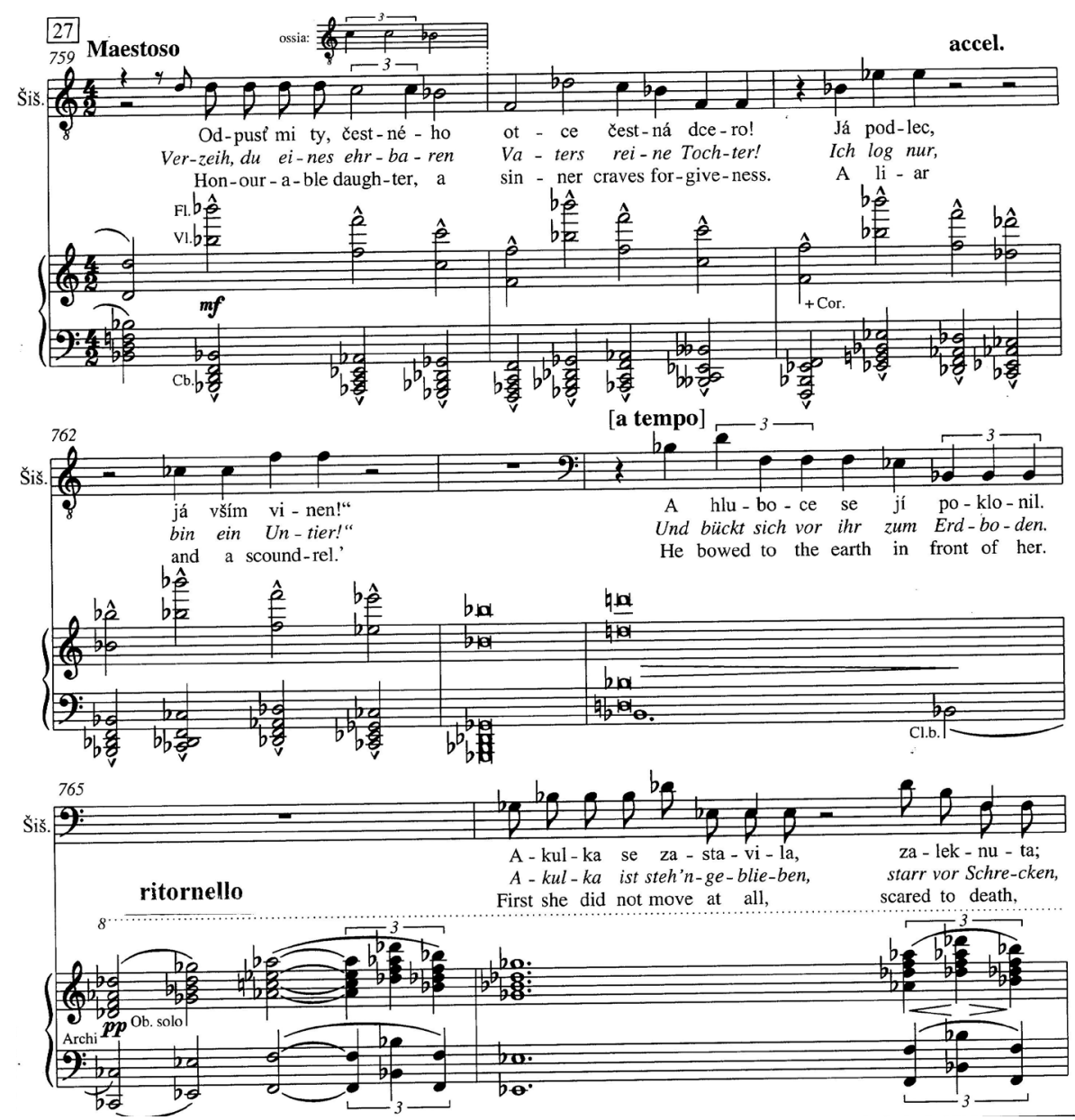

Example 6: Janáček: From the House of the Dead, Act 3. (C) With kind permission by Universal Edition A.G., Wien. www.universaledition.com

The use of maestoso comes with the words "Odpust" [Forgive me], recalling a similar maestoso moment at the end of Janáček's opera Jeni̊fa. The music is intensified by recalling the healing ritornello that runs through this monologue, associated with Akulka. These two examples have some- 
thing of the redemptive quality heard in examples above from Jenúfa and Makropulos.

What upsets Šiškov most is that Akulka (now his wife) readily forgives Filka. Her action seals her fate. In a two-bar maestoso passage he tells Akul$\mathrm{ka}$ that her end is come. What is striking about this final example is that Šškov's words are sung against the short and striking motif often known as the "motto theme" that dominates Act 1. This is the only instance where the maestoso in Janáček's autograph manuscript differs from that in the authorized copy. The latter has it in the position shown in the example; Janáček originally had it, less logically, two bars later.
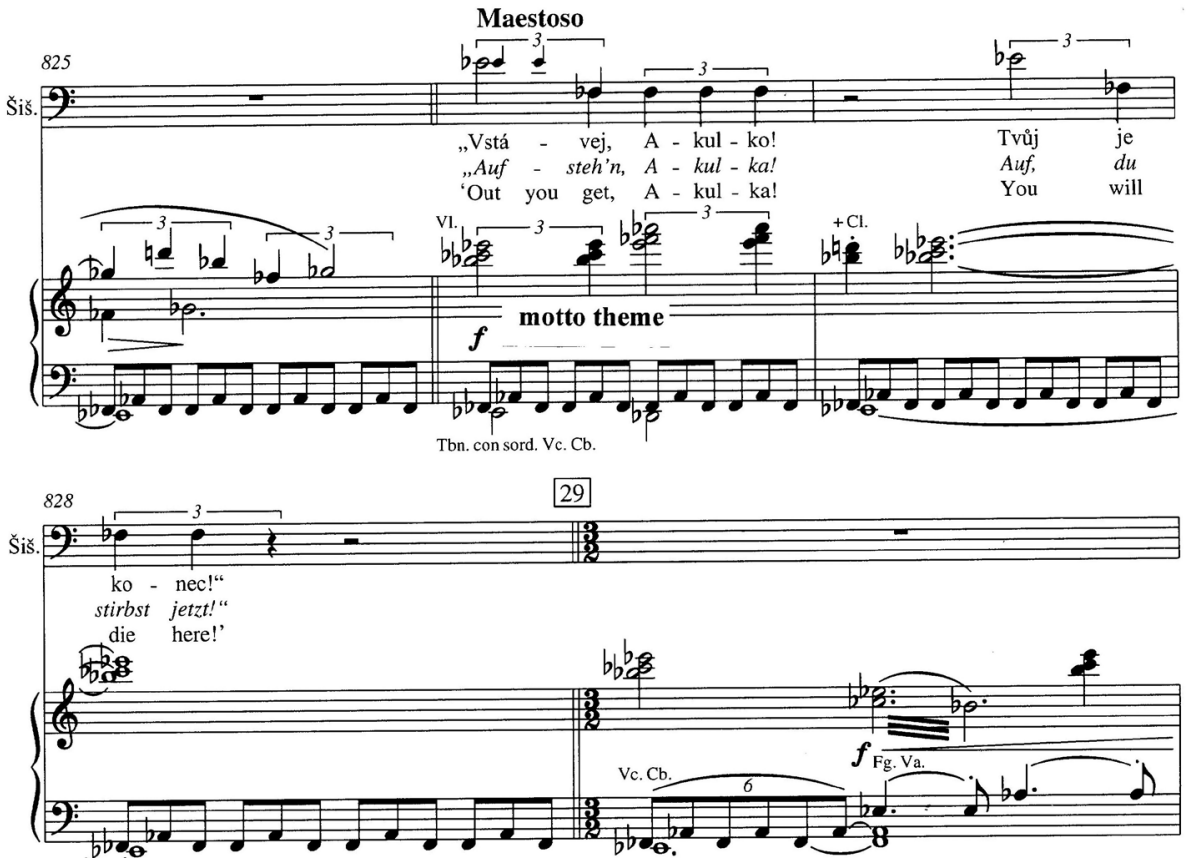

Example 7: Janáček: From the House of the Dead, Act 3. (C) With kind permission by Universal Edition A.G., Wien. www.universaledition.com

Soon after the beginning of the opera the prisoners in a Siberian prison camp await the arrival of the new prisoner, Alexander Petrovič Gorjančikov. This first maestoso in the act begins with the motto theme. There follows a very high, violin solo, set against low accompaniment, which seems to sug- 
gest the fear and loneliness of the man as he sees the prison for the first time.
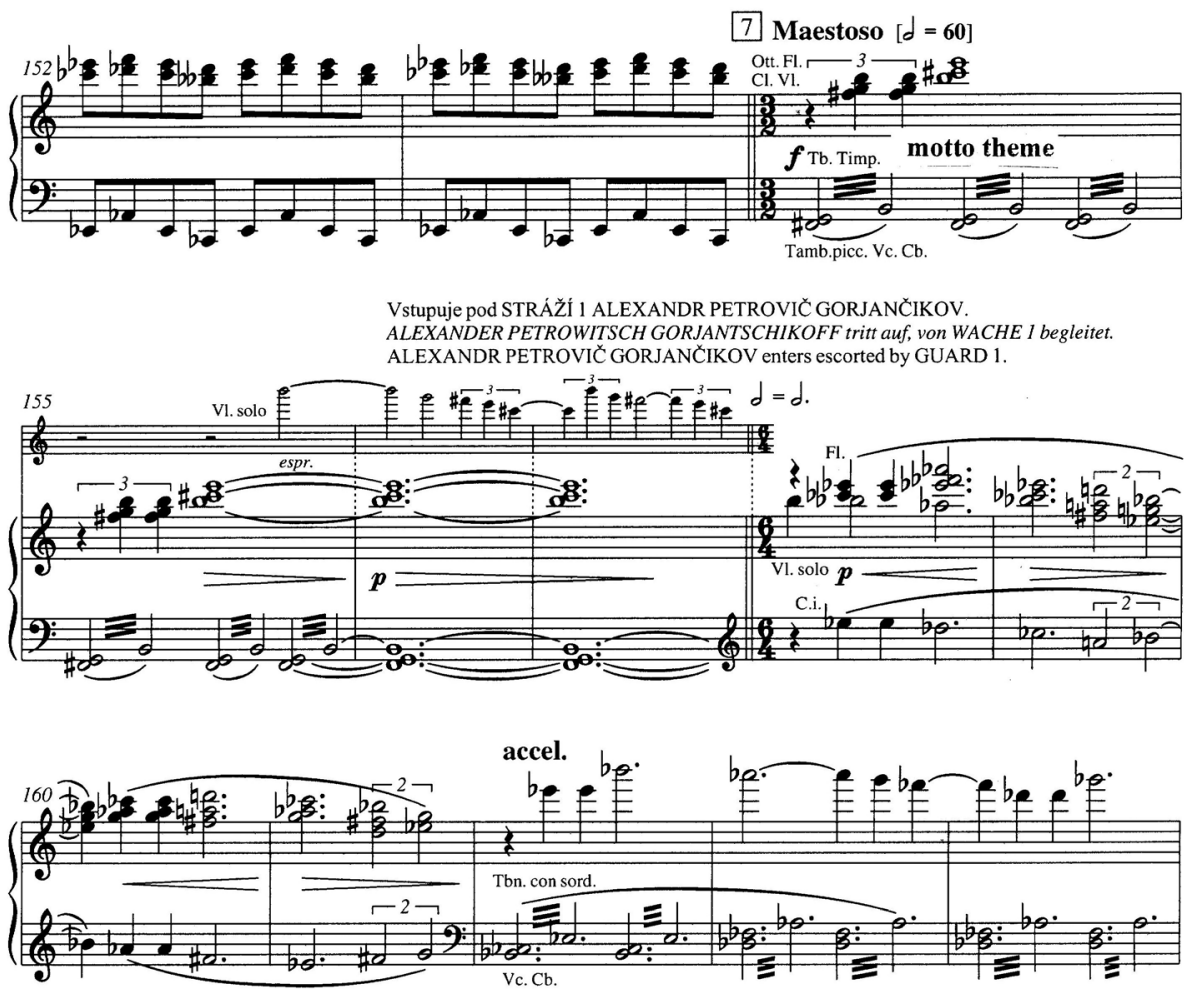

Example 8: Janáček: From the House of the Dead, Act I. (C) With kind permission by Universal Edition A.G., Wien. www.universaledition.com

Later in the act, one of the prisoners Skuratov, has gone almost mad in the prison. He does a wild dance and then collapses in exhaustion. Over repeated chords from the motto theme the rest of the prisoners comment saying that he is a useless imbecile. And, puzzlingly, this passage is marked maestoso (see ex. 10).

There are no occurrences of maestoso in Act 2, which is by far the most light-hearted act of the opera. But at the end of the short prelude to Act 3 there are three bars marked maestoso before the curtain goes up. They present a musical theme that is heard towards the end of the opera, associated with freedom. 


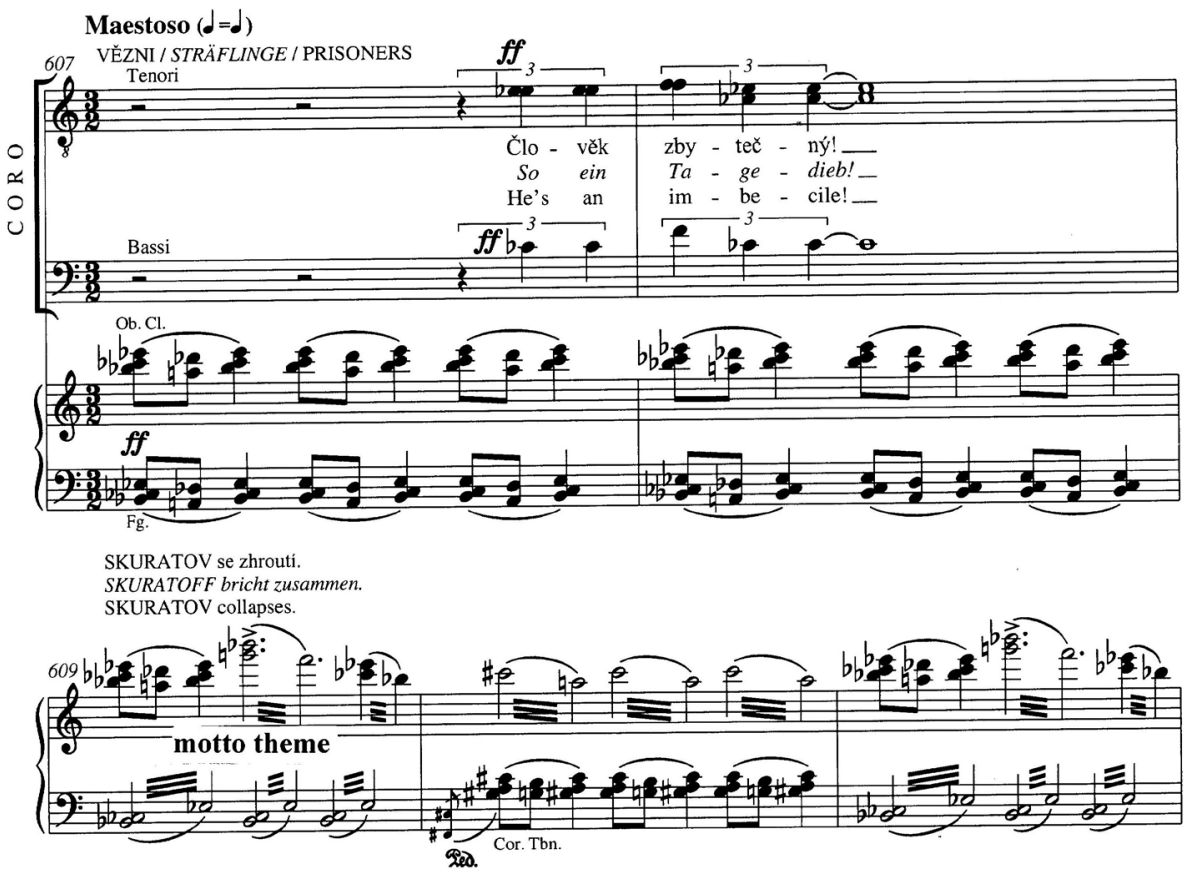

Example 9: Janáček: From the House of the Dead, Act r. (C) With kind permission by Universal Edition A.G., Wien. www.universaledition.com

At the end of the opera Petrovič is released from prison. He looks forward to his new life ("Nový život") and at the same time the other prisoners celebrate his freedom by letting the eagle out of the cage, its wing now healed. "Pust' ho Nikito!" they sing - repeating the words from Act 1 - and this time the eagle can fly and does fly. "Zlatá svoboda!" [Dear freedom] Petrovič sings to a repeat of the theme heard at the end of the Prelude. One might have expected this to be marked maestoso - but it is not.

As is evident there are more occurrences of maestoso here than in all of the previous three operas combined (eight compared with ten) and five of these $(\mathrm{C}, \mathrm{D}, \mathrm{F}, \mathrm{G}, \mathrm{H})$ include words, compared with three in the previous three operas. Only one of the House of the Dead examples is structural (the main use in the previous three opera). Three of the occurrences (B, D, $\mathrm{H})$ include one of the main musical themes of the opera, the motto theme. This theme opens Act 1 and recurs generally in association with painful events, for instance at the arrival of Petrovič in the prison camp and later during his brutal beating by the prison guards. It is heard when Skuratov 
has collapsed with exhaustion and is mocked by the other prisoners. And it is heard at the end of Šiškov's story when he tells Akulka that is about to kill her, both these passages ( $\mathrm{D}$ and $\mathrm{H}$ ) are marked maestoso.
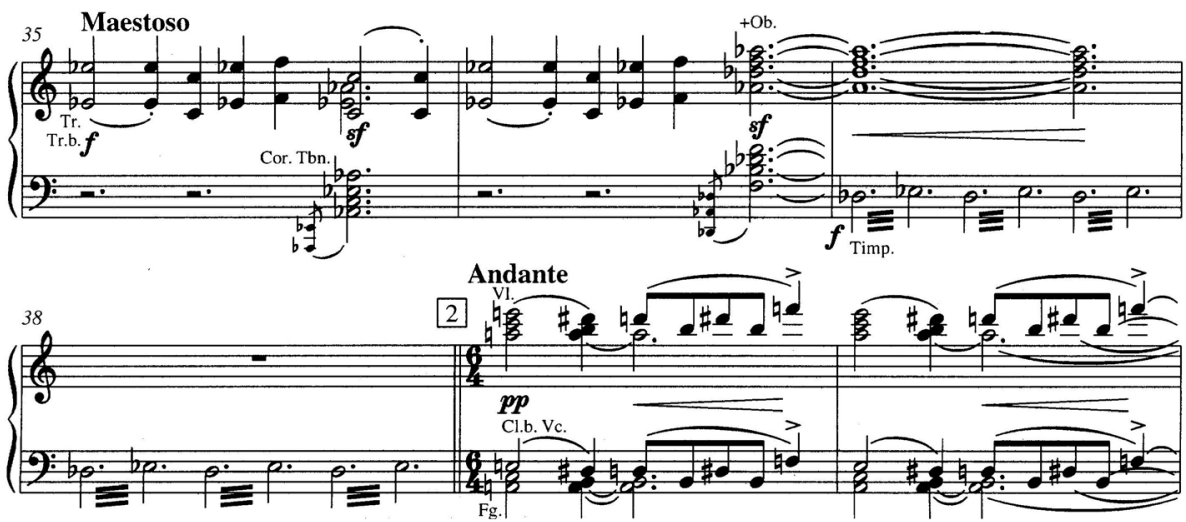

Example Io: Janáček: From the House of the Dead, Act 3. (C) With kind permission by Universal Edition A.G., Wien. www.universaledition.com

Most of the maestoso passages in From the House of the Dead are heard - unusually for Janáček - in sung passages and the words that are sung here perhaps provide a clue to Janáček's thinking. We have already noted two painful uses - with Skuratov and with the killing of Akulka. But equally there are others with positive associations. For instance when the prisoners tell Nikita to release the eagle, and the two moments of great tenderness and compassion, in Šiškov's story about Akulka.

Bearing in mind the original meaning of the term maestoso - majestically - and the earlier Czech preoccupation with its regal and heroic aspects, Janáček's use of the term in a prison setting and with common criminals, seems out of place. But we need to put these associations within the context of one more clue about Janáček's intentions in this opera. At the beginning of the score he wrote these words "V každém tvoru jiskra boži”" [In every creature a spark of God].

This thought is emphasized in the some lines found on Janáček after his death. In what seems to be notes for an article on the opera, he wrote:

Why do I go into the dark, frozen cells of criminals with the poet of Crime and Punishment? Into the minds of criminals and there 
I find a spark of God. You will not wipe away the crimes from their brow, but equally you will not extinguish the spark of God.

In From the House of the Dead the direction maestoso seems not so much an indication of how to play the music as a label to bestow dignity on his characters, to see in them this "spark of God". In this opera with a cast of criminals the indication that originally denoted and dignified Czech heroes is now used perhaps to suggest that even the dregs of society, the murderers that have been incarcerated in Siberian prisons, still retain their humanity. Janáček depicts their world and the terrible deeds they have done unflinchingly but also with huge compassion. And in what would be his final opera - almost his final work - he tries to find some sort of peace for them - forgiveness and a promise of freedom.

\section{Bibliography}

Koch, Heinrich Christoph. Musikalisches Lexikon, welches die theoretische und praktische Tonkunst, encylopädisch bearbeitet, alle alten und neuen Kunstwörter erklärt, und die alten und neuen Instrumente beschrieben, enthält. Frankfurt am Main: A. Hermann, 1802.

Simeone, Nigel, Tyrrell, John and Němcová, Alena. Janáček's Works: A Catalogue of the Music and Writings of Leoš Janáček. Oxford: Clarendon Press, 1997.

Tyrrell, John. "The Cathartic Slow Waltz and Other Finale Conventions in Janáček's Operas." In Essays on Drama and Music in Honour of Winton Dean, ed. Nigel Fortune. Cambridge University Press, 1987, 333-352.

Tyrrell, John. Janáček: Years of a Life, i: The Lonely Blackbird. London: Faber and Faber, 2006; ii: Tsar of the Forests. London: Faber and Faber, 2007.

Walther, Johann Gottfried. Musicalisches Lexicon, oder, Musicalisches Bibliothec. Leipzig: W. Deer, 1732. 